\title{
A STUDY OF LEARNERS' WRITING ANXIETY IN EFL CONTEXT
}

\author{
${ }^{\# 1}$ Ari Prasetyaningrum , ${ }^{* 2}$ Adib Nazri, ${ }^{* 3}$ Maman Asrobi \\ ${ }^{\# 1}$ English Lecturer, FBSH, Hamzanwadi University, Indonesia \\ ${ }^{* 2}$ English Lecturer, FBSH, Hamzanwadi University, Indonesia \\ ${ }^{* 3}$ English Lecturer, FBSH, Hamzanwadi University, Indonesia
}

Corresponding Author Email: ariprasetyaningrum@hamzanwadi.ac.id

\begin{abstract}
A B S T R A C T S
The present research purposes were to find the factors of students' writing anxiety and to know what the type of writing anxiety in writing encountered by the participants who followed writing for academic communication course of English education study program at Hamzanwadi University, Nusa Tenggara Barat, Indonesia. This study was categorized as descriptive quantitative method research. The researcher took 15 subjects who were chosen by using purposive sampling. The data collection methods were two closed-ended questionnaires, then second language writing anxiety inventor (SLWAI) designed by Cheng and Causes of Writing Anxiety Inventory (CWAI) proposed by Reraei and Jafari were applied to obtain the data. Observation and interviews were conducted to strengthen the result. The finding of research proved that the highest writing anxiety was avoidance behavior, which turned out the most predominant type among other types of writing anxiety which could be known from the highest mean score. Then there are four main causes that trigger writing anxiety. They were high frequency of writing assignments $(25,3 \%)$, low self-confidence in writing $(16,87 \%)$, and time pressure. $(10,79 \%)$, and problems with topic choice $(10,79 \%)$.
\end{abstract}

\begin{tabular}{l}
\hline A R T I C L E I N F O \\
\hline Article History: \\
Received: April, 2021 \\
Revised: May, 2021 \\
Published: June, 2021 \\
\hline Keywords: \\
Anxiety, \\
Foreign Language Anxiety, \\
Writing Anxiety, \\
\\
\end{tabular}

A R T I C L E I N F O

Article History:

Revised: May, 2021

Published: June, 2021

Keywords:

Anxiety,

Foreign Language Anxiety,

Writing Anxiety,

\section{INTRODUCTION}

Communication can not be created through speech only, but it can also be obtained through written media (Neuendorf \& Kumar, 2015). Someone may convey what she/he thinks then shares through printed media According to (Cheng, 2017), writing is a skill in a language that is applied in secondary interaction. As cited in (Phuket \& Othman, 2015), writing is the most complicated skill to understand by the second language students. The obstacles are not only in finding ideas and organizing them into the coherent paragraph but also in delivering thoughts in a text. There are several aspects needed in composing good written writing. There are several aspects needed in composing good written writing. San Rizqiya et al. (2017) said five aspects of writing, namely grammar, form, vocabulary, mechanic, and style. These aspects cause anxiety in writing even writing anxiety becomes situational. Lack of understanding of the previously mentioned aspects may probably cause uneasiness in writing even writing anxiety becomes situational. As Jawas (2019) finds that writing anxiety is situational. Anxiety has attracted the attention of the teachers and the linguist since the last decade. In Levitt 
(1980) anxiety refers to a feeling of being so afraid of something which will occur or has already occurred, then we keep thinking about it along the time or it can be a strong desire to accomplish a task, but we were very anxious that we will fail. $1 \mathrm{t}$ is related to feelings of uncomfortable, depression, lack of self-confidence, failure, or fright (Eslami et al., 2016). Based on various researches in real context of language instruction, anxiety is similar to the ability of foreign language. According to Huang (2018), general anxiety is one of affective aspects that may affect attention and finally brings to deterioration in language achievement. In conclusion, anxiety is absolutely having negative effect for those who experiences it.

Anxiety may influence either positively and negatively on one's performance (Thomas et al., 2017). It brings a significant effect on the writing skill of EFL students and most of it is supposed to be one of the basic barriers in the language process, yet sometimes a bit of anxiety is a must for concentration and accuracy of the learners during the writing process. Some non-experts in English as a foreign language teaching assume that anxiety has to be absent in each process, on the other hand, based on other theory like (McPherson et al., 2016), a little stress on something or on-going duty can be helpful sometimes. Thus, being so gentle towards the learners could lead to an enervating result to the learners, since they may be untroubled and have no worry and congregation. Writing means a demanding task that takes a long time to learn well. In addition, he said that certain learners who succeed in other lessons on writing were unsatisfied to several teachers who were too gentle to teach them write down precisely or take some procedures for them to trigger their close attention.Discussion on anxiety in foreign language learning should be interconnected to international communication context. Anxiety occurs in foreign and second language learning is unlike other types of anxieties since anxiety of language is a certain complicated structure of faith, notion, self-image, and manner that always exist in process of language learning that appears due to multiple processes during instructional activity (Král'ová, 2016). Furthermore, the anxiety of foreign language refers to a concept of stress and nerves especially related to language proficiency, including listening, writing, speaking, and reading. Though foreign language and second language anxiety are mostly shown by foreign or second language students and assumed as a typical matter, foreign language anxiety and second language anxiety are well understood as a main barrier of the learners to pursue second or foreign language for anxiety keeps contributing negative effect toward language proficiency (Subekti, 2018). The purposes of this study were to find the types of learners' writing anxiety and to know the causes of writing anxiety faced by the second-semester learners of the English study program in Hamzanwadi University who followed writing for academic communication.

Furthermore, foreign language anxiety is associated with three types of anxieties that link to pedagogical and social appraisal context. They are communication anxiety, fear of negative evaluation, and test anxiety (Alsowat, 2016). Communication anxiety means a type of insecurity known as apprehensive or worry to start communication with other people. Sometimes students will be timid and nervous when they have to involve in real communication, although they have quite developed in concept and notion as well. Actually, the students who often feel anxious will get more obstacles to create smooth communication using a different language that is not the first tongue due to the fact that they will think that their efforts at verbal process are being observed. That is why communication anxiety plays a significant influence to disorganize the steps of studying the second language or foreign language as students tend to suffer from depression at the time they express ideas in the second or foreign language. 
Fear of negative evaluation refers to uneasiness toward someone's else opinion, prevention of an uncomfortable environment, and suspicion that the auditor will convey negative judgment to him. The anxiety of negative opinion does not only happen when taking an examination time but also occurs in every public, critical moments like an interview for a job application or convey a speech in second or foreign language courses.

Test anxiety is defined as a kind of performance worry that emerges due to failure fright. Fear of unsuccessful happens due to the fact that the learners have an opinion that the best performance is proved if they could accomplish an examination as perfectly as possible. Test anxiety has a significant role in learners' learning results, some feel like the anxiety of failure or troublesome experience are examples of examination apprehensive which sometimes affected students' performance.

Anxiety in writing could occur because of internal and external factors. The internal factor comes from the personality of the learners, meanwhile, the external factor comes from the process when the students learn writing. Alike the anxiety in foreign language learning, anxiety found in certain skills like writing anxiety is also classified into several types.

Writing anxiety types are grouped into three namely, cognitive anxiety which relates to uncomfortable experience of cognitive aspect, including negative suspicion, distraction on self-performance, and bothers to someone else's viewpoint. The process of how learners create their paragraphs might be relatively affected by the revision offered by their classmates as well as the lecturers. Then, somatic anxiety is defined as someone's interpretation of mental reaction to the apprehension situation, like restlessness as well as rigidity. Occasionally, learners suffer from severe tension if they face limited time yet they do not find any ideas to organize their paragraph, and the last is avoidance behavior which is defined as a condition when learners ignore to write. This is a behavioral aspect of the apprehension cases. This is the most threatening of writing anxiety as the learners loathe to write. Consequently, they cannot show satisfying performance during writing lessons and will not produce high achievement on their test as well.

Worry in writing appears because of particular conditions, previous studies revealed that there are nine causes of writing anxiety. Those reasons are first, the anxiety of writing. A large number of learners are afraid of someone else evaluation of their product of writing, and anxiety of tests is very troublesome due to the fact that writing examination is considered as a productive activity that is affected by time limitation. The learners will be very anxious when their essay writing is not as impressive as the teacher's expectation then their teacher will say negative comments. The second is time pressure. Writing in English for students takes much more time than writing in their native language. Rezai and Jafari (2014) found that time pressure is a prominent cause of writing because the learners have to plan, write, organize and revise to ensure that their paper in English can be acceptable and those activities take extra time. Often, the learners feel distressed when they should produce an essay writing under time pressure since they are unable to focus on their written product. The third is low self-confidence in writing. Self-confidence is very significant in improving the students' interest in the tasks given. When the students who have good second language writing skill assumes that they are unable to write a text-based on the organized, they cannot avoid anxiety in writing. Fourth is insufficient writing technique. Learners with writing anxiety have low skill development and poor knowledge of the organizing steps that means the worried learners are not capable to write. The fifth cause is linguistic difficulties. The language barrier is often encountered by English as a foreign language learner to organize a composition which finally makes them reluctant to write a text because of the problems to express thoughts into various and right phrases and clauses which must be arranged 
based on grammar principles. In addition, the vocabulary stock of the students is still insufficient. Therefore, they find problems producing their composition in a foreign language. Sixth is a problem with topic choice. Learners' anxiety is sometimes caused by a low level of topical knowledge. For example, if the learners are given a task by the lecturer to write an essay on the issue of language teaching, yet they only have limited insight, they will be confused and doubtful to put down their own thoughts. They are demanded to think of an idea that is unfamiliar and far from their daily life. Therefore, it can be concluded that low knowledge affects writing anxiety among students. Seventh is insufficient writing practice. A reason why learners feel uneasy when writing English essays is due to insufficient practice in English written expression. The learners who are reluctant to do writing tasks during the writing course will put the most focus on the writing forms, instead of the essay content. Eight is pressure for perfect work. Anxiety may happen if the learners get demand to obtain the best test result. They feel that the most acceptable essay is that which resulted in a high score and high standard. The learners wish to reach high expectation in writing which cause them to experience writing anxiety and the ninth cause is a high frequency of writing assignments. The ninth basic cause of writing anxiety is a high frequency of assignments. According to Wern \& Rahmat (2021), the high frequency of assignments is one of the causes of anxiety in writing However, the percentages of the respondents from the study who chose it as a cause of writing anxiety are a few and it becomes the least chosen item by the respondents. On the other hand, this study showed a different result than the high frequency of writing assignments is the main cause of writing anxiety.

There are a lot of researchers who found the factors influenced writing ability. Herdi (2015, p.20) in his research which was conducted in English Education Department in FKIP at Lancang Kuning University Pekanbaru revealed certain component affected the learners' text. Here, he mentioned components influenced writing skill significantly. Those were media, the atmosphere in class, classroom administration, teacher's methods and techniques.

Some factors that contribute to the learners' writing products are media applied by the lecturer to facilitate instructional activity in order to attract the learners' interest and spirit during attending a lecturing process. In addition, the media could ease the lecturer to deliver the goal of learning and to facilitate the lecturers to organize the lesson during when they teach. Then, the classroom atmosphere plays a significant role in the learners' writing ability. In this study, the lecturer implemented all steps of writing techniques like prewriting, whilst-writing, and post-writing. Every step of writing strategies may affect the students' writing ability as these efforts trigger the learners to be an enthusiast and innovative in writing class. Various activities may affect the learners' writing ability in order that they could do a lot of effort in writing well. Next is classroom administration of writing courses which affects the learners' writing ability. If the classroom administration was running well, the instructor can facilitate as well as guide the learners during the instructional process. Another important factor is a method which the teachers apply to teach their learners that may trigger the learner's ability in writing. The teachers may assist the learners to understand the lesson effectively. The last matter which may affect the improvement of learners' writing proficiency was the lecturers' technique during the instructional process. The lecturers could assist, facilitate, and stimulate the learners during the knowledge transfer process.

Nowadays, educators of language and linguist experts have evaluated the effect of apprehension toward foreign language proficiency (Aydin, 2018). Late studies revealed that foreign language apprehension is a common kind of anxiety in which the dominant aspect relates to oral skill, yet the newest studies found anxiety entwine to various 
languages like listening, writing reading, and speaking. In the research conducted by (Bellinger et al., 2015) about test anxiety it was shown that situation-trait which the discrepancy of the subject's inability was a threat. 1n a study by (Steinhart \& Jiang, 2019), ego threat" nature causes a common feeling of anxiety by switching worries to positive self-image and the result of achievement or failure, as well as, unfavorable judgment by someone else. Rycroft (2018) spotted three basic aspects of anxiety: affective: the one's opinion about his/her mental health (e.g. moving, perspiring, having a headache, stomachache, stress, etc.); cognitive: discredit self-feelings and thoughts of the students say for example "if 1 do not pass this examination 1 do not know what to do anymore" and worry on certain memory in the past that may cause as an inhibiting influence on the pupils' achievement (e.g. several presentation mistakes in reading to comprehend the passage and its tasks); and behavioral: lack ability to grasp a language, avoiding and put off of homework.

This study has relevance to a research conducted by Wahyuni \& Umam (2017) under the title An Analysis on Writing Anxiety of Indonesian EFL College Learners in STAIN Kediri, Indonesia. The purpose of this research was to find out English learners' writing anxiety at an Islamic State College in East Java, 1ndonesia. The research result showed that $54 \%$ of the learners were categorized into writing anxiety of high level, $44 \%$ was categorized into the middle level of writing anxiety, and $2 \%$ was grouped into writing anxiety of low level. The most prominent category of writing anxiety was cognitive writing anxiety, which in fact was the highest mean among two other kinds of writing anxiety. Furthermore, there are four important aspects that influence writing anxiety. They are linguistic barriers, the anxiety of lecturers' unfavorable evaluation, inadequate writing exercise, and time constraints.

Having analyzed the research conducted by the previous researchers, this study also deals with anxiety in writing, and the authors were inspired to find out the factors that caused writing anxiety as well as the types of writing anxiety faced by the learner who took writing for general communication in English education study program at Hamzanwadi University. By the end of the study, the writing anxiety factors were graded to know which one is the most dominant to the least significant.

\section{RESEARCH METHOD}

The research design applied in this study was the descriptive quantitative method. The descriptive quantitative method refers to a research approach where the researcher gathers and examines quantitative data and qualitative data in one research. Mohajan (2018) states descriptive quantitative research is an investigation that provides a picture of a phenomenon as it naturally occurs, as opposed to studying the impacts of the phenomenon or intervention. At times, the descriptive quantitative method deals with what, how, and what happened in the past. Hence, the authors applied a descriptive quantitative method to know how is writing anxiety in EFL students. This study intended to reveal the common types and the main causes of writing anxiety. Fifteen students of the English education study program in the second semester who attended a writing for academic communication course were chosen to participate in this study.

\section{Research Design}

The design applied in this research is descriptive quantitative design by using purposive sampling to choose the participants. Mohajan (2018) states descriptive research is defined as a research method that describes the characteristics of the population or phenomenon studied. A study is said as describtive quantitative if it measure certain variables such as the main discussion of this study which aim to analyze the types of writing 
anxiety as well as causes of writing anxiety faced by the participants. Furthermore, this study is classified as a descriptive study because its purpose is to describe the types of writing anxiety and causes of writing anxiety through the use of simple descriptive calculation such as mean, percentage and data analysis. Data finding of the research is conducted by class observation, interview', and give questionnaire then make the interpretation from the result comparison.

\section{Subject}

Participants of the study are some people who take part in research that were selected based on the research question, theoretical perspectives, and evidence. In this research, the present researcher took 15-second semester students of the English education study program at Hamzanwadi University who took writing for academic communication as the participants of the research. The present researcher used purposeful sampling in choosing the participants.

\section{Instruments}

The present researcher used two types of close-ended questionnaires which consisted of 22 items, Second Language Writing Anxiety Inventory (SLWAI) designed by Cheng (2004) and the Causes of Writing Anxiety Inventory (CWAI) initiated by Rezaei and Jafari (2014a). SLWAI invented by Cheng (2004) was one of the most valid instruments to measure writing anxiety, exactly for the second and foreign language, close-ended interview, and classroom observation (to collect data based on what the present researcher discovers at the classroom).

\section{Data Analysis}

For data collection steps, two types of questionnaires were used, they were Second Language Writing Anxiety Inventory (SLWAI) by Cheng (2004) and the Causes of Writing Anxiety Inventory (CWAI) by Rezaei and Jafuri (2014a). The questionnaire comprised 22 information as well as adopted a Likert-type 5-option response type: 1 (strongly disagree), 2 (disagree), 3 (neither agree nor disagree), 4 (agree), and 5 ( strongly agree). Division of questionnaire points were divided into three subcategories as follows: Cognitive Anxiety (1 ,3,7,9,14,1 7,20,21 ), Somatic Anxiety (2,6,8,1 1,13,15,19), and Avoidance Behavior $(4,5,10,12,16,1 b, 22)$. The research finding found that SLWAI contains accurate internal consistency reliability, respectable test-retest reliability, sufficient convergent and satisfying measurement-related validity (Cheng, 2004, p. 331).

The use of the Cause of Writing Anxiety Inventory (CWAI) was to find out several aspects which influence writing anxiety. It was designed on the factors writing anxiety causes such as fear of teacher's negative comment, fear of writing test, insufficient writing practice, insufficient writing technique, the problem with topic choice, linguistic difficulties, pressure for perfect work, high frequency of writing assignment, time pressure, and low self-confidence in writing (Rezai and Jafari, 2014). Apart from the questionnaire, the present study also conducted an interview test on the participants in order to confirm their previous answers. The present researcher employed close-ended interview'. The present researcher compared the result of the questionnaire with the interview' section to decide the factors and type of the students' anxiety in writing. The present researchers also did classroom observation in which how the teaching and learning process activity runs during writing course was observed, and analyzed the students' problems and progress in writing skill. The present researcher wrote some notes. then combine the result with the questionnaire and interview section. 
First, to classify the item/answer based on its category: Cognitive Anxiety, Semantic Anxiety, and Avoidance Behavior. Item numbers 1, 3, 7, 9, 14, 20, 21 were for Cognitive Anxiety: item numbers of 2, 6, 8, 11, 13, 15, 19 were for Somatic Anxiety, and items number 4, 5, 10, 12, 16, 18, 22 were for Avoidance Behavior. There was seven number $(1,4,7,18,19,21,22)$ in SLWAl that were worded negatively and needed contrary scoring before being summarized to gain the whole scores for three categories. The author counted the mean of learners' answers on every category of anxiety in writing. From the highest to the lowest mean types of writing anxiety encountered by the participants were monitored.

Second, a questionnaire called Analyzing Causes of Writing Anxiety Inventory (CWAI) was applied to classify the primary causes which lead to anxiety in writing. The first step to examine the learners' answers is by multiplying every calculation outcome of any single point of the questionnaire. CWAI questionnaire had 10 points of a question mark on a five-point Likert response scale starting from the point I (strongly disagree), 2 (disagree), 3 (neither agree nor disagree), 4 (agree), and finally 5 (strongly agree). Having multiplied the outcome with Likert point, the whole mark was summarized to get the percentage. The highest percentage was determined as the main type of anxiety in writing.

Third, after finding the data analysis, the author drew some conclusions. Having analyzed and compared the questionnaires, observation, and interview results, the present author sorted the type and the causes of writing uneasiness experienced by the learners.

\section{RESEARCH FINDINGS AND DISCUSSION Research Findings}

In this study, the authors use two types of close-ended questionnaires namely, second language writing anxiety inventory (SLWAI) by Cheng (2014), and Causes of Writing Anxiety Inventory (CWAI) by Rezael and Jafari (2014). Second language writing anxiety inventory (SLWAI) is used to know the types of writing anxiety, and Cause of Writing Anxiety inventory is applied to know the most prominent causes of writing anxiety. The research findings are described as follows:

\section{Types of Writing Anxiety}

In order to understand the most frequent kind of writing apprehension, the author calculates the mean of each classification of writing anxiety which follows Second Language Writing Anxiety Inventory (SLWAI) questionnaire. Having analyzed SLWAI questionnaires, the author sorts the participants' class of writing anxiety into three types; those were cognitive anxiety, somatic anxiety, and avoidance behavior. The mean of every category is shown in table 1.

Table 1

The Mean of Each Category of Writing Anxiety

\begin{tabular}{cccc}
$\begin{array}{c}\text { Writing anxiety } \\
\text { types }\end{array}$ & $\begin{array}{c}\text { Number of } \\
\text { student }\end{array}$ & $\begin{array}{c}\text { Total } \\
\text { score }\end{array}$ & Mean \\
\hline Cognitive & 15 & 770 & 51.3 \\
\hline Somatic & 15 & 551 & 36.7 \\
\hline $\begin{array}{c}\text { Avoidance } \\
\text { behaviour }\end{array}$ & 15 & 815 & 54.3
\end{tabular}


Table 1 shows that the mean score of cognitive anxiety is 51.3, somatic anxiety is 36.7, and avoidance behavior 54.3. Avoidance behavior is the highest mean, cognitive anxiety comes the second, and somatic behavior has the lowest mean. Avoidance behavior is the most dominant mean among two other types of writing anxiety which means that Avoidance Behavior becomes the highest cause of writing anxiety.

\section{Causes of Writing Anxiety}

To obtain a clear understanding of the root causes of writing anxiety, the questionnaire of the Causes of Writing Anxiety Inventory is used. The author writes a recapitulation table of CWAI and shows the data into percentages. The result of CWAI is displayed in Table 2.

Table 2

The Percentage of Each Item of CWAI

\begin{tabular}{clcc} 
No & Factors of Writing Anxiety & Total & Percent \\
\hline 1 & Fear of lecturer's negative comments & 54 & 6.07 \\
\hline 2 & Fear of writing tests & 48 & 5.39 \\
\hline 3 & Insufficient writing practice & 42 & 4.72 \\
\hline 4 & Insufficient writing technique & 72 & 8.09 \\
\hline 5 & Problems with topic choice & 96 & 10.79 \\
\hline 6 & Linguistic difficulties & 80 & 8.99 \\
\hline 7 & Pressure for perfect work & 26 & 2.92 \\
\hline 8 & High frequency of writing assignments & 225 & 25.3 \\
\hline 9 & Time pressure & 96 & 10.79 \\
\hline 10 & Low self-confidence in writing & 150 & 16.87 \\
\hline & & 889 &
\end{tabular}

From table 2, the main decisive element of why writing anxiety is encountered by the students is a high frequency of writing tasks $(25.3 \%)$. It is the highest percentage among nine causes of writing anxiety. High frequency of writing tasks refers to the number of writing tasks that they get while at the same time they also had to accomplish different genres of texts with various topics followed by low self-confidence in writing $(16.87 \%)$. The next causes are problems with topic choice $(10.79 \%)$ and time pressure $(10.79 \%)$. The most dominant factors are chosen based on the highest percentages among the ten causes of writing anxiety.

The calculation of ten main factors of writing anxiety stand on the percentage is a high frequency of writing tasks, low self-confidence in writing, time pressure, problems with topic choice, linguistic difficulties, insufficient writing technique, fear of lecturer's negative comments, fear of writing examination, insufficient writing practice, pressure for perfect work

\section{Discussion}

This study analyzes a core question of the writing anxiety experienced by the EFL students exactly the second-semester students of Hamzanwadi University who followed writing for academic communication. Jebreil et al. (2015) state that writing anxiety analysis relates to a kind of apprehension in performance that arise from fault the uneasiness of failure arises when the students have ideas that their tolerable performance created when they follow writing course as perfect as possible if they fail to accomplish the tasks well; it means that the result of the test will completely unsuccessful. Writing anxiety plays a significant impact on students' achievement in learning, certain suspicions like fright of 
failure or troublesome experience are kinds of anxiety that commonly affect the learners' mental (Wern \& Rahmat, 2021).

The result of the data findings presents that there are categories of writing anxiety and the particular causes of writing anxiety. This proves that the participants, especially those who study English in an Indonesian teaching and learning field often face cognitive, somatic, and avoidance behavior anxiety which is caused by fear of teacher's negative comments, fear of writing test, insufficient writing practice, insufficient writing technique, problems with topic choice, linguistic difficulties, pressure for perfect work, high frequency of writing assignment, time pressure and low self-confidence in writing. This implies that the learners who have problems in writing anxiety have to understand the anxiety causes and try to solve their own anxiety disorder during a writing course. The result of the present study shows that writing anxiety causes failure in organizing a text (Bayat, 2014). Bayat (2014) states that writing problematic conditions will hamper the students from achieving writing proficiency in language learning. Similarly, (Özmen \& Altun, 2014) emphasize that writing anxiety is one of the fundamental obstacles which prevent language learners to gain high achievement in language learning.

The research purposes are to reveal learners' writing anxiety the prominent types and the principal causes which trigger anxiety in writing skill among the second-semester students in English education study program of Hamzanwadi University which followed English for Academic communication which are the second sequence of writing course followed by the students after writing for general communication and before writing for a professional course. Having analyzed the kinds of anxiety in writing, avoidance behavior was the main kind of writing anxiety encountered by the learners (Jebreil et al., 2015). The mean score of avoidance behavior was 54.3. The next kind of writing anxiety is cognitive anxiety with a mean score 51.3, and the least type of writing anxiety is somatic anxiety with a mean score 36.7 .

In line with the relevant researches about writing anxiety types, the authors find similarities aims and conducted for EFL learners in the study belong to Rezai and Jafari (2014). They conduct a study to investigate the levels, types, and causes of writing anxiety among Iranian EFL students. By applying the mixed method, they find that cognitive anxiety is the most dominant type of writing anxiety, on the other hand, this research reveals a new finding that avoidance behavior has the highest percentage among writing anxiety type with $54.3 \%$ among 15 students. The students experienced avoidance behavior when they are uninterested in learning writing and following the procedures to make each paragraph. It is due to the fact that the learners cannot produce proper paragraph which can be developed into an essay (Sabti et al., 2019). Avoidance anxiety is a type of anxiety in which the students keep away from writing. This is anxiety experience deals with the behavior aspect (Xiao \& Wong, 2014) For instance, the students do not attend the writing class or reluctant to accomplish writing exercises. It is the riskiest type of writing anxiety because the students will loathe writing. They will be reluctant to attend a lesson in a writing class. The students cannot get maximum results on their course. It was risky writing anxiety type because if this condition happen the students would underestimate writing task and test as well. Behavioral symptoms of anxiety include hand squeezing, or finger tipping.

Cognitive anxiety comes to the second type of writing anxiety faced by the learners $(51.3 \%)$ from 15 learners. (Wern \& Rahmat, 2021) reveals that cognitive anxiety is known to be the mental aspect of anxiety experience, whereby writers are preoccupied with negative thoughts about the performance and being considerate about other's impressions of their written work for the statement 'worry about getting poor English composition grade', followed by to reverse scoring statement of 'don't worry that English compositions being worse than others with mean score and next with the statement 'worried and uneasy if comp. 
A study conducted by Wern and Rahmat (2021) which investigates the types and causes of ESL Writing anxiety in Chinese Independent Middle School found that cognitive anxiety becomes the most dominant anxiety type.

The least common type of anxiety is somatic anxiety which takes $36.7 \%$ out of the other types of writing anxiety. Somatic Anxiety is said to be the physical symptoms manifested from the writing experience, which elevates the state of anxiety feelings, and tension (Wern \& Rahmat, 2021). The characteristics of somatic anxiety are ' heart goes pounding under time constraint English composition writing', ' mind goes blank when writing English essay writing' and ' whole-body is stiff and tight when writing English essays. The finding of somatic anxiety as the least study about type of writing anxiety conducted by Zhang (2011) in which she analyzed ESL (English as Second Language) writing anxiety among Chinese English Major. Zhangs' finding shows that the most frequent type of writing anxiety experienced by her participants is cognitive anxiety with a mean score 25.08 . The next frequent type of anxiety is avoidance behavior with a mean score 21.77 whereas the least frequent anxiety is somatic anxiety with a mean score 19.64.

Furthermore, the most prominent causes of writing anxiety are the high frequency of writing assignments (25.3\%), low self-confidence in writing (16.87\%), time pressure $(10.79 \%)$, and (and problems with topic choice (10.79\%). The first basic cause of writing anxiety is a high frequency of assignments. The high frequency of writing assignments may become the prime factor of writing anxiety (Ningsih, 2015). The learners were worried to accomplish a lot of assignments that they have. They are challenged to do a lot of tasks at the same time and it probably makes their ideas stuck in writing English, then feel anxious (Robichaud et al., 2019). According to Rezaei \& Jafari (2014), high frequency of assignments is one of the sources of writing anxiety. It was strengthened by the highest percentages of the respondents from the study who choose it as the most common cause of writing anxiety and it becomes the most chosen cause by the participants.

The second main factor of writing anxiety is low self-confidence (Kirmizi \& Kirmizi, 2015). 1t may occur due to certain reasons such as lack of linguistic difficulties, insufficient writing practice, and insufficient writing technique and lack of understanding of linguistics include grammar as well as vocabulary. In the writing process, we require the items mentioned previously to gain writing expertise to make the readers catch the meaning easily (Dirgeyasa, 2017). Therefore, the learners who have low self-confidence will get worried to write. Even the students who have good English writing who assume that they are not competent to organize a paragraph will not be able to avoid writing anxiety.

Thirdly, time pressure might because of low confidence when doing the writing (Hammad, 2016). They do not have enough experience in writing English. It leads the students into anxiety (Elaldi, 2016). Writing in English for learners requires more time than writing in their first language. They will long hours to think, write a draft, ordering paragraphs, and edit in order to convince themselves that the result in English can be correct like writing in their first language. The learners are worry if they are demanded to write under time pressure because they are unable to focus on their writing, and pay attention to a time limitation only. The tasks for journal writing and reviewing could provide a lot of chances for the learner to be good at writing. Time pressure becomes one of the root causes of writing anxiety is similar to the study done by Rezaei and Jafari (2014), who identified that time pressure is one of the main causes of Writing in English for EFL students, as more time is needed second or foreign language writing.

The last is the problem with the topic choice which have the same percentage as time pressure. It also might invite low confidence feeling. The writing technique is a crucial element in gaining a good writing outcome. They might feel doubt in the writing 
process. This is because of the complications faced in applying organization of the text, purposes, and the grammar rule according to various clauses and problematic to find the suitable word choices for the topic and to express their ideas (Bennui, 2016). This finding is strengthened by the research result of (Syarifuddin, 2020) who accomplished a study entitled survey on EFL students' writing anxiety level, types, and causes. He found that linguistics difficulties (82\%), lack of topical knowledge (68\%), and insufficient writing technique $(60 \%)$ are the dominant sources of students' writing anxiety.

As stated in the introduction that the purposes of this research are to find the types of writing anxiety and to know the causes of writing anxiety experienced by the second semester of the English Department in Hamzanwadi University who took writing for an academic communication course, the data findings reveal that writing anxiety types found in the study are avoidance behavior, cognitive and somatic. The causes of writing anxiety experienced by the participants are high frequency of writing assignments, Low selfconfidence in writing, Time pressure, Problems with topic choice, Linguistic difficulties, Insufficient writing technique, Fear of teacher's negative comments, Fear of writing tests, Insufficient writing practice and Pressure for perfect work respectively from the highest to the lowest percentage. The potential limitation of this study is an insufficient number of participants in which there are 15 learners involved (less than the whole number of students in a classroom) and another limitation is this research only analyzed students who attended writing for academic communication as the second sequence in writing course after writing for general purposes and writing and before writing for a professional context. In fact, each type of writing course has its own characteristics and purposes. This implies that writing lecturers have an important role in teaching writing for their learners. Having observed the research finding of types and causes of writing anxiety, lecturers should be able to reduce the anxiety of students by using proper strategies efficiently. Wern \& Rahmat (2021) found strategies in writing such as affective strategies, positive error revision, and vocabulary understanding improvement. Basically, writing anxiety comes from the students and environment, yet the lecturers also have an important role in it. They should evaluate their method in teaching and understanding their student need to achieve good progress in writing. In a conclusion, there were two roots that cause students to experience anxiety in writing. The first is from the students such as low self-confidence, insufficient writing technique, language difficulties, lack of topical knowledge, and lack of experience or insufficient writing practice. These problems could be solved by the students. Other friends or environments may assist the anxious students. The second is from the environment, such as fear of negative evaluation, time pressure, pressure for perfect work, and high frequency of writing assignments.

\section{CONCLUSION}

Having described the data in the findings and the discussion section, the author drew some conclusions. Avoidance behavior (54.3\%) was the dominant kind of anxiety in writing. Then the next type of writing anxiety was cognitive anxiety (51.3\%), and the last type of writing anxiety went to somatic anxiety (36.7\%). Avoidance behavior refers to the students' behavior to avoid using English as an option to write. They try hard to avoid writing English, they tend to use other languages than English. The main factors that cause writing anxiety are the high frequency of writing assignments, low self-confidence in writing, as well as time pressure, and the problem with topical choice.

\section{REFERENCES}

Alsowat, H. H. (2016). Foreign language anxiety in higher education: A practical framework for reducing FLA. European Scientific Journal, 12(7). 
Aydin, S. (2018). Technology and foreign language anxiety: Implications for practice and future research. Dil ve Dilbilimi Çallşmaları Dergisi, 14(2), 193-211.

Bayat, N. (2014). The Effect of the Process Writing Approach on Writing Success and Anxiety. Educational Sciences: Theory and Practice, 14(3), 1133-1141.

Bellinger, D. B., DeCaro, M. S., \& Ralston, P. A. S. (2015). Mindfulness, anxiety, and highstakes mathematics performance in the laboratory and classroom. Consciousness and Cognition, 37, 123-132.

Bennui, P. (2016). A study of L1 interference in the writing of Thai EFL students. Malaysian Journal of ELT Research, 4(1), 31.

Cheng, Y,-S. (2004). A measure of second language writing anxiety: Scale development and preliminary validation. Journal of Second Language Writing, 13, pp. 313-15.

Cheng, Y. (2017). Development and preliminary validation of four brief measures of L2 language-skill-specific anxiety. System, 68, 15-25.

Dirgeyasa, I. W. (2017). College Academic Writing A Genre-Based Perspective. Prenada Media.

Elaldi, S. (2016). Foreign Language Anxiety of Students Studying English Language and Literature: A Sample from Turkey. Educational Research and Reviews, 11(6), 219228.

Eslami, A. A., Rabiei, L., Afzali, S. M., Hamidizadeh, S., \& Masoudi, R. (2016). The effectiveness of assertiveness training on the levels of stress, anxiety, and depression of high school students. Iranian Red Crescent Medical Journal, 18(1).

Hammad, E. A. (2016). Palestinian university students' problems with EFL essay writing in an instructional setting. In Teaching EFL writing in the 21st century Arab world (pp. 99-124). Springer.

Herdi, H. (2015). An Analysis on Factors Influencing the Students' Writing Skill. ELTLectura, 2(2). https://doi.org/10.31849/elt-lectura.v2i2.465.

Huang, H.-T. D. (2018). Modeling the relationships between anxieties and performance in second/foreign language speaking assessment. Learning and Individual Differences, 63, $44-56$.

Jawas, U. (2019). Writing anxiety among Indonesian EFL students: Factors and strategies. International Journal of Instruction, 12(4). https://doi.org/10.29333/iji.2019.12447a.

Jebreil, N., Azizifar, A., Gowhary, H., \& Jamalinesari, A. (2015). Study on writing anxiety among Iranian EFL students. International Journal of Applied Linguistics and English Literature, 4(2), 68-72.

Kirmizi, Ö., \& Kirmizi, G. D. (2015). An Investigation of L2 Learners' Writing SelfEfficacy, Writing Anxiety and Its Causes at Higher Education in Turkey. International Journal of Higher Education, 4(2), 57-66.

Král'ová, Z. (2016). Foreign language anxiety. Undergraduate of Constantine the Philosopher University, Nitra, Slovakia.

Levitt, E. E. (1980). The Psychology of Anxiety: Second Edition (1st Ed.). Routledge. https://doi.org/10.4324/9781315673127.

McPherson, S., Hiskey, S., \& Alderson, Z. (2016). Distress in working on dementia wards-a threat to compassionate care: a grounded theory study. International Journal of Nursing Studies, 53, 95-104.

Mohajan, H. K. (2018). Qualitative research methodology in social sciences and related subjects. Journal of Economic Development, Environment, and People, 7(1), 23-48.

Neuendorf, K. A., \& Kumar, A. (2015). Content analysis. The International Encyclopedia of Political Communication, 1-10. 
Ningsih, T. A. (2015). The Study of Foreign Language Writing Anxiety among English Department Students of Faculty of Letters, Jember University. Repository Universitas Jember. http://repository.unej.ac.id/handle/123456789/72598.

Özmen, B., \& Altun, A. (2014). Undergraduate students' experiences in programming: difficulties and obstacles. Turkish Online Journal of Qualitative Inquiry, 5(3), 1-27.

Phuket, P. R. N., \& Othman, N. B. (2015). Understanding EFL Students' Errors in Writing. Journal of Education and Practice, 6(32), 99-106.

Rezaei, M., \& Jafari, M. (2014). Investigating the levels, types, and causes of writing anxiety among Iranian EFL students: A mixed method design. Procedia-Social and Behavioral Sciences, 98, 1545-1554.

Robichaud, M., Koerner, N., \& Dugas, M. J. (2019). Cognitive behavioral treatment for generalized anxiety disorder: From science to practice. Routledge.

Rycroft, C. (2018). Anxiety and neurosis. Routledge.

Sabti, A. A., Md Rashid, S., Nimehchisalem, V., \& Darmi, R. (2019). The Impact of Writing Anxiety, Writing Achievement Motivation and Writing Self-Efficacy on Writing Performance: A Correlational Study of Iraqi Tertiary EFL Learners. SAGE Open, 9(4). https://doi.org/10.1177/2158244019894289.

San Rizqiya, R., Pamungkas, M. Y., \& Inayah, R. (2017). The use of POWER learning as a learning strategy to improve students writing competency. OKARA: Jurnal Bahasa Dan Sastra, 11(2), 253-262.

Steinhart, Y., \& Jiang, Y. (2019). Securing the future: Threat to self-image spurs financial saving intentions. Journal of Personality and Social Psychology, 117(4), 741.

Subekti, A. S. (2018). An Exploration of Learners' foreign Language Anxiety in The Indonesian University Context: Learners' and Teachers' voices. TEFLIN Journal, 29(2), 219-244.

Syarifuddin, H. M. (2020). Communication Strategies Used By The Lecturers in Teaching Speaking Subject at English Department of Muhammadiyah University Of Makassar [Unpublished Master Thesis]. English Department: Muhammadiyah University of Makassar.

Thomas, C. L., Cassady, J. C., \& Heller, M. L. (2017). The influence of emotional intelligence, cognitive test anxiety, and coping strategies on undergraduate academic performance. Learning and Individual Differences, 55, 40-48.

Wahyuni, S., \& Umam M. K. (2017). An Analysis on Writing Anxiety of Indonesian EFL College Learners. JEELS: Journal of English Education and Linguistics Studies, 4(1), 105-128. https://doi.org/10.30762/jeels.v4i1.333.

Wern, T. C., \& Rahmat, N. H. (2021). An Investigative Study on the Types and Causes of ESL Writing Anxiety: A Case Study of Learners from a Chinese Independent Middle School. European Journal of English Language Teaching, 6(3).

Xiao, Y., \& Wong, K. F. (2014). Exploring heritage language anxiety: A study of Chinese heritage language learners. The Modern Language Journal, 98(2), 589-611.

Zhang, H. (2011). A study on ESL writing anxiety among Chinese English majors - Causes, effects and coping strategies for ESL writing anxiety [Unpublished Master Thesis]. Kristianstad University. 